\title{
Application of FMEA in an Automatic Component Insertion Equipment in an Electronic Industry
}

\author{
Douglas da Silva Marques, João Gabriel Marinho Maciel, Marcelo Albuquerque de Oliveira, \\ Gabriela de Mattos Veroneze, Dercio Luiz Reis, and Joaquim Maciel da Costa Craveiro
}

\section{ABSTRACT}

One of the consequences of globalization was an increase in the response between companies. In this way, companies increasingly seek continuous improvement using various mechanisms and tools aimed at improving their processes, products, and services, thus making them more competitive. In this scenario, FMEA stands out as a unique tool for detecting and reducing failures in products and processes in order to improve their confidence. This article is the result of the study of the application of the FMEA in an equipment to the production process of insertion of components. For this, action research was carried out, where equipment failure data was collected. As a result, a 5W2H action plan was prepared with the support of a GUT matrix to apply the recommended improvements in the FMEA.

Keywords: Continuous Improvement, Failure, FMEA.
Submitted : September 11, 2021

Published : December 02, 2021

ISSN: $2507-1076$

DOI: $10.24018 /$ ejbmr.2021.6.6.1102

Douglas da Silva Marques*

Graduation student in Production Engineering, Federal University of Amazonas, Brazil.

(e-mail: douglassm25@gmail.com)

João Gabriel Marinho Maciel

Graduation student in Production Engineering,

Federal University of Amazonas, Brazil.

(e-mail: jgabrimm@ gmail.com)

Marcelo de Albuquerque de Oliveira

Professor, PhD, Master's Program in

Production Engineering, Federal University of Amazonas, Brazil.

(e-mail: marcelooliveira@ ufam.edu.br)

Gabriela de Mattos Veroneze

Professor, PhD, Master's Program in

Production Engineering, Federal University of

Amazonas, Brazil.

(e-mail: gveroneze ${ }^{\circledR}$ ufam.edu.br)

Dercio Luiz Reis

Professor, PhD, Master's Program in

Production Engineering, Federal University of Amazonas, Brazil.

(e-mail: dercioreis@ufam.edu.br)

Joaquim Maciel da Costa Craveiro

Professor, $\mathrm{PhD}$, Master's Program in

Production Engineering, Federal University of Amazonas, Brazil.

(e-mail: jmaciel@ufam.edu.br)

*Corresponding Author

\section{INTRODUCTION}

In the current globalized scenario, the industry is highly competitive, changeable, and demanding. In order to keep the industries competitive, it has used many mechanisms, quality and management tools, new technologies and collaborator qualification so that they can highlight themselves against their competitors.

Within this context, the maintenance sector of industries has become a means of cost reduction, process and products' quality improvement or services provided. Using the tools that focus on the better and continuous efficacy of maintenance plans, this sector has been gaining highlight within the process.

Within the tools that highlight the FMEA (Failure Mode and Effects), that translated would be the mode and effect of failure analysis, created in the 50th decade for military purposes, although from the 80th decade started to be used in the industry to analyse processes and product's failure. The FMEA is the starting point to the reliability analysis of products, processes and systems aiming to identify, organize, correct, and prevent potential failures of them.

At last, this study has as the main objective, the application of FMEA in an automatic component insertion equipment. With the direct action inside of an electronic industry installed in Industrial Pole of Manaus, this article aims to demonstrate the improvements and possibilities that the FMEA provides to the company's productive process. 


\section{LITERATURE REVIEW}

\section{A. FMEA}

According to Puente et al. (2002), around 1963, while the Apollo mission occurred, NASA had formulated a method to identify systematically the potential failures in systems, processes or, even, services before these eventual issues occurred. Therefore, it has been the beginning of the concept of Failure Mode and Effect Analysis (FMEA).

In an industry, the FMEA can be understood as a methodology that allows identifying potential failures within a certain system or process, with the purpose to discard or reduce the risks related, aiming to eliminate future failures. Thereby, putting an end in the failure modes.

To Stamatis (1995), the FMEA is a technique of product or process analysis used to detect all the possible potential failure modes and to see the effect of each one over the performance of the system, with basically deductive reasoning. Thus, a pattern analytical methodology to diagnose and eliminate potential issues of a complete and systematic mode.

In accordance with Palady (2004), the FMEA is one of the methods of low risk more efficiently to forestall issues and identify effective solutions in cost terms, seeking to prevent problems. Besides that, the FMEA has the duty to analyse the severity of the failures, the way that they can happen and, once they happen, how to detect and correct them.

According to Teles (2017), FMEA is a technique of qualitative analysis that shapes information into quantitative data. When the maintenance is elaborate, the FMEA is one of the most significant tools to be used, because of the following reasons:

- Failure mode determination: It can come from engineering or from the field. Data fields are more considerable, once they represent all the failures that a process can have.

- Risk analysis of each failure mode: the priority of which failure mode goes through three steps: failure severity determination (the scale of how ban it will be if it happens), failure occurrence determination (frequency of how much it happens) and failure detection probability determination (how easy it is to happen).

- RPN calculation (risk priority number): It is the calculation of multiplication of the occurrence values, severity and detection. It's a way to know which failure mode starts.

Teles (2017) complements that RPN stands for Risk Priority Number. The attention is defined by the result of Occurrence X Severity X Detection, the bigger the result, the bigger the priority ought to be to that point of the process. The three parameters presented can be attributed to punctuations from 1 to 10 .

In accordance with Horita (2020), the FMEA utilization entails the minimization of the failure of the product or process, so, in the face of the methodology application. The reliability is contributed directly (Chhim et al., 2019; Estorilio and Posso, 2010; Meng, 2011; Niu et al., 2010; Pun et al., 2002; Shafiee, 2015; Tian et al., 2018).

FMEA methodology is applied in several areas of knowledge, resulting in significant improvements in processes, according to the work of different authors
(Rausand and Øien, 1996; Al-Hammad et al., 2009; Irajpour et al., 2014; Murthy et al., 2002; Oliveira et al., 2015; Oliveira et al., 2012; Batista et al., 2019).

\section{B. $5 \mathrm{~W} 2 \mathrm{H}$}

According to [20] the $5 \mathrm{~W} 2 \mathrm{H}$ is a tool created by a Japanese automobility industry, which is an administrative tool that can have application in many business areas and in different contexts in an organization. The main purpose of $5 \mathrm{~W} 2 \mathrm{H}$ is to help plan the actions once it assists to clear doubts and free them from doubts about a certain issue.

From this, its use can generate benefits, such as adjust ideas and organize perspectives. The tool has been functioning similar to a checklist, in which it contains seven questions. The questions are: What? (What will be done?); Why? (Why will it be done?); Where? (Where it will be done?); When? (When it will be done?); Who? (By whom will it be done?); How? (How it will be done?) and How Much? (How much will it cost?) (Oliveira et al., 2015).

\section{C. $5 \mathrm{~W} 2 \mathrm{H}$}

Napoleão (2018) highlights that the GUT matrix is used by companies with the aim to define the prioritization of problems that need to be attacked by the management, such as discovering the priority of some activities that must be done or developed. The used tool, for example, in problem solving, developing projects, decision making, within others.

The acronym is formed by the words Gravity, Urgency and Tendency (Periard, 2011). The Gravity symbolizes the problem impact studied in case it happens. Urgency is defined by the deadline, the free or necessary time to resolution of the issue. Tendency portraits the potentiality of the problem growth, it is the probability of the problem growing according to time.

\section{Methodology}

It has used the research-action methodology taking into account that the research has been carried out in partnership with the industrial maintenance team of the company.

It is a qualitative and quantitative approach, once the study has as its aim the FMEA application, which approaches qualitatively and generates quantitative data, within an equipment to the insertion process of the company's compounds.

Initially, the choice of the equipment to apply to the FMEA. It has been chosen the CM-602 PANASONIC once it is an equipment of high quality in the productive lines of the company, with 14 units, also as being the chief of the insertion line of electronic compounds.

After it has been done, the subdivision of the equipment within systems, at this moment there has been the participation of the maintenance team of the company that supported the technical part of the study. After this division, it has been done the failure modes survey was already predefined by the manufacturer, according to the machine's manual.

Subsequently, there was the data collection from the maintenance manager, in which we filtered the CM-602 failure modes, where it has been verified the occurrences of it in the period of January to July of 2020, classifying each 
failure mode according to its respective system within the equipment.

\section{RESULTS AND DISCUSSIONS}

To the data analysis, it has been used some tools as spreadsheets, graphics, FMEA and GUT matrix. The following Table 1 shows the subdivision done in the equipment to better identification and localization of the failure modes.

TABLE I: EQUIPMENT SUBDIVISION

\begin{tabular}{cc}
\hline \hline Machine Model & Structure \\
\hline Head assembly & Conveyor \\
Vacuum system & Linear guides \\
CM602 Panasonic & Feed car \\
& Base camera \\
Electronic system & Nozzle change \\
Electrical system \\
Monitor \\
Safety system \\
Cutter \\
\hline \hline
\end{tabular}

After that, it has been done the data collection of the failure's occurrence in each subsystem of the equipment. It has been used as a data bank of the company's maintenance team. The following graphic shows the quantity of failure modes of each subsystem.

During the data collection and definition of the modes and failures, it has been determined that the head of the CM-602 mounting is where the potential failures of the equipment occurred, followed by the Conveyor and the vacuum system. The three subsystems total $50 \%$ of the failure modes surveyed in the data collection during the evaluated period, as shown in Fig. 1.

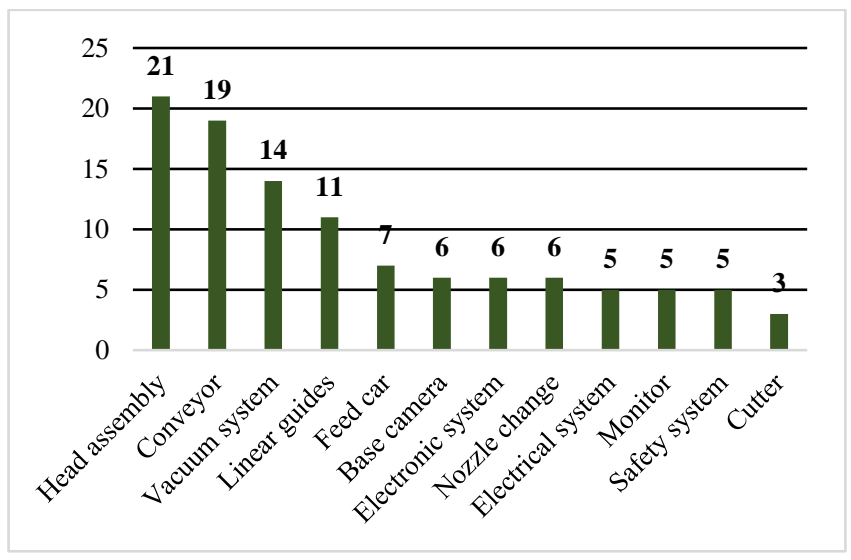

Fig. 1. Quantity of Failures.

From the data survey, it has been done the FMEA elaboration, doing the failure analysis relating to its failure mode, effect, and possible cause, allocating by subsystem of the equipment.

Lastly, after the NPR calculation, it can be recommended preventive actions to each failure in the FMEA, taking into account the need and priority of each action. Based on the information elaborated by the FMEA, it has been elaborated a starting action plan to be applied.

It has been used GUT matrix for the prioritization of the action of the maintenance team, taking into account that these actions must pass through a management analysis. The GUT matrix classification has been done by the PCM analyst according to the needs of the management.

Table II shows the action plan consolidated after the FMEA implementation study for the equipment.

\section{CONCLUSION}

Globalization had, among many consequences, increased competitiveness between companies. Through this way, the companies each time look more for continuous improvement using many mechanisms and tools that enhance its processes, products and services, becoming more competitive.

Then, the study consisted of FMEA application in automatic component insertion equipment of an IPM's company, with the aim to reduce equipment failures, provide data to the maintenance plan and be an example to be applied in another equipment.

Based on this information, it has been elaborated on the FMEA equipment and from it has been used the $5 \mathrm{~W} 2 \mathrm{H}$ methodology closely with the GUT matrix to propose an action plan based on the recommended actions in the study.

Although, there was a limitation of the action plan application, because the company's maintenance sector had changed the management. Therefore, it was not possible to compare the actions made before and after of the actions taken. At last, it is recommended the follow-up after the action is implemented and verification of the improvement occurred, thus it can be a model study to be replicated in the future in other companies' equipment giving this way a possibility of the reliability increase of the productive process.

\section{ACKNOWLEDGMENT}

The authors thank the Production Engineering Department (DEP) of the Federal University of Amazonas (UFAM) for their support and structure.

Special acknowledgement to the institutions and people involved to the final consolidation of this work that has been authorized through the agreement 001/2020 from the Cooperação Técnico-Científica celebrated between Fundação Universidade do Amazonas (FUA), Fundação de Apoio ao Ensino, Pesquisa, Extensão e Interiorização do IFAM (FAEPI) and the company Samsung Eletrônica da Amazônia LTDA (SEDA-M), within the project's scope of capacitation and research, which has been done by the academic unity FTUFAM. 
TABLE II. 5W2H ACTION PLAN

\begin{tabular}{|c|c|c|c|c|c|c|c|c|c|c|}
\hline What to do? & Why to do? & $\begin{array}{l}\text { Where will it } \\
\text { be done? }\end{array}$ & \multicolumn{2}{|c|}{ When to do it? } & \multirow{2}{*}{$\begin{array}{c}\text { Who will do it? } \\
\text { Responsible }\end{array}$} & \multirow{2}{*}{$\begin{array}{c}\text { How to do this? } \\
\text { How/Resources/Process }\end{array}$} & \multicolumn{4}{|c|}{ GUT Matrix } \\
\hline Action & Reason/Consequence/Effect & Area & $\begin{array}{l}\text { Expected } \\
\text { start }\end{array}$ & $\begin{array}{l}\text { Expected } \\
\text { end }\end{array}$ & & & Grav. & Urg. & Tend. & Prior. \\
\hline $\begin{array}{l}\text { Survey the Part Numbers of } \\
\text { the parts identified in the } \\
\text { FMEA for registration in } \\
\text { stock }\end{array}$ & $\begin{array}{l}\text { Minimize machine downtime due to } \\
\text { lack of parts }\end{array}$ & $\begin{array}{c}\text { IAC } \\
\text { Maintenance }\end{array}$ & $25 / 01 / 2020$ & $08 / 02 / 2020$ & $\begin{array}{l}\text { Maintenance } \\
\text { Technician }\end{array}$ & Using the equipment manual & 3 & 4 & 5 & 12 \\
\hline $\begin{array}{l}\text { Carry out the registration of } \\
\text { parts for purchase and } \\
\text { inclusion in stock }\end{array}$ & $\begin{array}{l}\text { Minimize machine downtime due to } \\
\text { lack of parts }\end{array}$ & $\begin{array}{c}\text { IAC } \\
\text { Maintenance }\end{array}$ & $11 / 02 / 2020$ & $12 / 02 / 2020$ & $\begin{array}{l}\text { Maintenance } \\
\text { Technician }\end{array}$ & $\begin{array}{l}\text { Via registration spreadsheet sent to } \\
\text { the registration sector }\end{array}$ & 2 & 3 & 2 & 7 \\
\hline $\begin{array}{l}\text { Inclusion of activities raised } \\
\text { in MFMEA in the } \\
\text { maintenance plan }\end{array}$ & $\begin{array}{l}\text { Improved maintenance plan based } \\
\text { on our MFMEA analysis }\end{array}$ & $\begin{array}{c}\text { IAC } \\
\text { Maintenance }\end{array}$ & $24 / 01 / 2020$ & $30 / 01 / 2020$ & $\begin{array}{l}\text { Maintenance } \\
\text { Technician }\end{array}$ & $\begin{array}{l}\text { Add to the maintenance plan in the } \\
\text { maintenance manager }\end{array}$ & 3 & 3 & 2 & 8 \\
\hline $\begin{array}{l}\text { Create troubleshooting based } \\
\text { on defect analysis performed } \\
\text { in MFMEA }\end{array}$ & $\begin{array}{l}\text { Improvement in the maintenance } \\
\text { stoppages made by the production }\end{array}$ & $\begin{array}{c}\text { IAC } \\
\text { Maintenance }\end{array}$ & $17 / 01 / 2020$ & $22 / 01 / 2020$ & $\begin{array}{l}\text { Maintenance } \\
\text { Technician }\end{array}$ & $\begin{array}{l}\text { Using the data collected during the } \\
\text { completion of the MFMEA }\end{array}$ & 5 & 3 & 2 & 10 \\
\hline $\begin{array}{l}\text { Perform HEAD Check } \\
\text { programming with Panasonic } \\
\text { to anticipate failures }\end{array}$ & $\begin{array}{l}\text { Predictive maintenance of failures } \\
\text { in HEADS }\end{array}$ & $\begin{array}{c}\text { IAC } \\
\text { Maintenance }\end{array}$ & $25 / 01 / 2020$ & $11 / 02 / 2020$ & $\begin{array}{l}\text { Maintenance } \\
\text { Technician }\end{array}$ & $\begin{array}{l}\text { Conducting quotation process with } \\
\text { Panasonic and closing the schedule } \\
\text { according to equipment availability }\end{array}$ & 5 & 3 & 2 & 10 \\
\hline $\begin{array}{l}\text { Develop predictive } \\
\text { maintenance in the company } \\
\text { to implement predictive } \\
\text { maintenance actions }\end{array}$ & $\begin{array}{l}\text { Deployment of predictive } \\
\text { maintenance in IAC }\end{array}$ & $\begin{array}{c}\text { IAC } \\
\text { Maintenance }\end{array}$ & $25 / 01 / 2020$ & $25 / 02 / 2020$ & $\begin{array}{l}\text { Maintenance } \\
\text { Technician }\end{array}$ & $\begin{array}{l}\text { Conducting survey and development } \\
\text { of suppliers }\end{array}$ & 5 & 3 & 2 & 10 \\
\hline $\begin{array}{l}\text { Development of a tensiometer } \\
\text { for belt analysis }\end{array}$ & $\begin{array}{l}\text { Minimize process stoppages due to } \\
\text { broken belts and transport-related } \\
\text { problems }\end{array}$ & $\begin{array}{c}\text { IAC } \\
\text { Maintenance }\end{array}$ & $24 / 01 / 2020$ & $22 / 02 / 2020$ & $\begin{array}{l}\text { Maintenance } \\
\text { Technician }\end{array}$ & $\begin{array}{l}\text { Conducting survey and development } \\
\text { of suppliers }\end{array}$ & 5 & 3 & 2 & 10 \\
\hline
\end{tabular}




\section{REFERENCES}

Al-hammad, S. Assaf, \& M. Al-Shihah. (1997) The effect of faulty design on building maintenance. Journal of Quality in Maintenance Engineering, 3(1), 29-39.

Batista, S.; Oliveira, M. A., Reis, D.; Veroneze, G.; Maciel, R. (2019). Application of FMEA for improvement in the manufacturing process of mobile phones in a factory of the Industrial Pole of Manaus. International Journal for Quality Research, 13(4), 1021-1036. https://doi.org/10.24874/IJQR13.04-18.

Chhim, P., Chinnam, R. B., and Sadawi, N. (2019) Product design and manufacturing process-based ontology for manufacturing knowledge reuse. J. Intell. Manuf., 30(2), 905-916.

Estorilio, C., \& Posso, R. K. (2010). The reduction of irregularities in the use of "process FMEA". International Journal of Quality and Reliability Management, 27(6), 721-733. https://doi.org/10.1108/02656711011054579.

Horira F. (2020) Trabalho de FMEA.http://fge.if.usp.br/ fhorita/FMEA.htm. Irajpour, A., Fallahian-Najafabadi, A., Mahbod, M. A., and M. Karimi. (2014) A framework to determine the effectiveness of maintenance strategies lean thinking approach. Math. Probl. Eng., vol. 2014.

Meng, J. W. J. (2011) Total Productive Maintenance in Manufacturing Industry in Malaysia. (Doctoral dissertation, Universiti Teknologi Malaysia).

Murthy, D. N. P., Atrens, A., and Eccleston, J. A. (2002) Strategic maintenance management. J. Qual. Maint. Eng., 8(4), 287-305.

Napoleão, B. (2018) "5W2H." Ferramentas da Qualidade. https://ferramentasdaqualidade.org/5w2h/.

Niu, G., Yang, B. S., and Pecht, M. (2010) Development of an optimized condition-based maintenance system by data fusion and reliabilitycentered maintenance. Reliab. Eng. Syst. Saf., 95(7), 786-796.

Oliveira, M. A., Lopes, I. (2019) Evaluation and improvement of maintenance management performance using a maturity model". Int. J. Product. Perform. Manag., 69(3), 559-581.

Oliveira, M. A., Lopes, I. S., and Figueiredo, D. L. (2012) Maintenance Management Based on Organization Maturity Level. Proceedings of the International Conference on Industrial Engineering and Operations Management, pp. 1-10.

Oliveira, M. A., Lopes, I. S., and Figueiredo, D. L. (2014) Survey on maintenance area of companies of the manaus industrial pole. Transactions on Engineering Technologies: World Congress on Engineering and Computer Science, pp. 501-514, 2015.

Palady, P. (2004) FMEA: Análise dos Modos de Falha e Efeitos: prevendo e prevenindo problemas antes que ocorram. Imam, ISBN $9788589824316,269 \mathrm{p}$

Periard, G. (2011) Matriz GUT: Guia Completo. Sobre Administração. http://www.sobreadministracao.com/matriz-gut-guia-completo/.

Puente, J., Pino, R., Priore, P., and De La Fuente, D. (2002) A decision support system for applying failure mode and effects analysis. Int. J. Qual. Reliab. Manag.

Pun, K., Chhin, K., Chow, M., and Lau, H. C. W. (2002) An effectivenesscentred approach to maintenance management: A case study. J. Qual. Maint. Eng., vol. 8, no. 4, pp. 346-368.

Rausand, M., and Øien, K. (1996) The basic concepts of failure analysis. Reliab. Eng. Syst. Saf., 53(1), 73-83.

Shafiee, M. (2015) Maintenance strategy selection problem: An MCDM overview. J. Qual. Maint. Eng., 21(4), 378-402.

Stamatis, D. H. (1995) Failure mode and effect analysis: FMEA from theory to execution. ASQ Quality Press; 2nd Edition, ISBN-13: 9780873893008,494 p.

Teles, J. (2017) FMEA: O que é e como fazer. https://engeteles.com.br/fmeao-que-e-como-fazer.

Tian, J. J., Sun, N., Song, L., Yang, Z. F., Zeng, H. J., and Fei, F. (2018) Research on Failure Modes of Defective Gasoline Engine Product Based on Pareto Diagram. International Conference on Civil and Hydraulic Engineering, 189(6), 18.

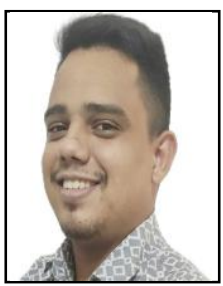

Douglas da Silva Marques is a student of Production Engineering at the Federal University of Amazonas, and researcher under SUPER project.

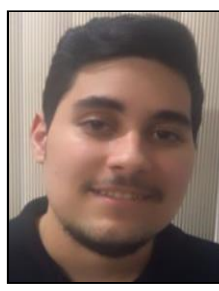

João Gabriel Marinho Maciel is a student of Production Engineering at the Federal University of Amazonas, and researcher under SUPER project.

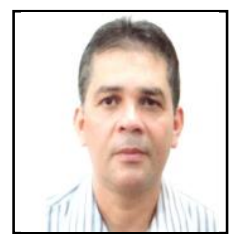

Marcelo Oliveira is an Adjunct Professor of Department of Production Engineering and member of Master Program in Production Engineering, Federal University of Amazonas. He has published several Research Papers related to Engineering area.

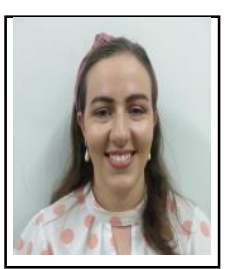

Gabriela Veroneze is an Adjunct Professor, Department of Production Engineering and member of Master Program in Production Engineering, Federal University of Amazonas. She has published several Research Papers related to Engineering area.

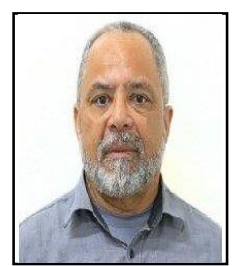

Dércio Reis is an Adjunct Professor, Department of Production Engineering and member of Master Program in Production Engineering, Federal University of Amazonas. He has published several Research Papers related to Engineering area.

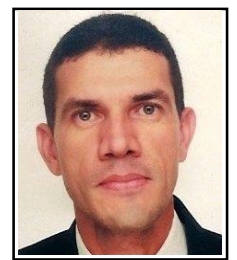

Joaquim Craveiro is an Adjunct Professor, Department of Production Engineering and member of Master Program in Production Engineering, Federal University of Amazonas. He has published several Research Papers related to Engineering area. 